Çukurova Üniversitesi Mühendislik Mimarlık Fakültesi Dergisi, 30(2), ss.,227-241, Aralık 2015

Çukurova University Journal of the Faculty of Engineering and Architecture, 30 (2), pp. 227-241, December 2015

\title{
Güncel İş Kazaları Verilerinin İstatistiki Analizi
}

\author{
Ayten ESER ${ }^{* 1}$ \\ ${ }^{1}$ Çukurova Üniversitesi, Mühendislik Mimarlık Fakültesi, Maden Mühendisliği Bölümü, Adana \\ Geliş tarihi: 09.11.2015 \\ Kabul tarihi: 30.12 .2015
}

\section{Özet}

İş kazaları, ulusal çapta faaliyet gösteren tüm alanlarda ciddiyetle üzerinde durulmaya başlanan önemli konuların başında gelmektedir. Bu gün kanunlarla desteklenen, denetlenen ve kontrol altına alınmaya çalışılan bir ifade olarak önümüzde durmaktadır. Gelecekte hangi durumlarla karşılaşacağımızı öngörebilmek, çalışma yöntemlerini doğru seçebilmek ve alınacak tedbirleri düzenlemek için yakın geçmişten yararlanmak gerekmektedir. Ulusal verileri kullanılarak, iş kazalarına güncel bir bakış sunan bu çalışmada, kazaların sonuçları çeşitli değişkenler kullanılarak sorgulanmıştır. Faaliyet kolları, kaza zamanlaması ve bunlara bağlı ölüm ve geçici iş göremezlik sayıları incelenmiştir.

Çalışmada, kaza-zaman yoğunluğu tespit edilmiş ve iş kazalarının zamanlama modeli oluşturulmuştur. Aynı şekilde, mühendislik çalışmalarının iş kazalarının en yoğun olduğu ana faaliyet kolu olduğu ortaya çıkmıştır. Benzer şekilde, inşaat ve madencilik çalışmalarının, kayıpların en çok meydana geldiği faaliyet kolları olduğu tespit edilmiştir. Bu çalışmada ayrıca, iş kazasına bağlı ölümler ile yıllar arasında regresyon analizi ortaya konmuştur.

Anahtar Kelimeler: İş kazası, Mühendislik faaliyetleri, Kaza-zaman yoğunluğu, Regresyon analizi

\section{Statistical Data Analysis of Current Work Accidents}

\begin{abstract}
Work accidents are among the key issues which begun to be addressed seriously in all areas operating nationwide. Today, these accidents are stands as an expression which supported, audited and controlled by law. It is necessary to take advantage of the recent past to predict what situations we face in the future, be able to select the correct operating procedures and to arrange the precautions. In this study which offering an updated overview of work accidents by using national data, the consequences were investigated by different variables. Operating branches, accident timing and the number of death and temporary incapacity for work were examined.

In the study, the intensity of accident-time was determined and timing of work accidents is modeled. Also, the engineering work appeared to be main branch of the most intense work accidents. Likewise, it is determined that construction and mining operations are the branches that most losses occurred. Also in this study demonstrated regression analysis between the years with death due to work accidents.
\end{abstract}

Keywords: Work accidents, Engineering activities, Accident- time intensity, Regression analysis

\footnotetext{
* Yazışmaların yapılacağı yazar: Ayten ESER, Mühendislik Mimarlık Fakültesi, Maden Mühendisliği Bölümü, Adana, agulmez@cu.edu.tr
} 


\section{GíRiş}

$\mathrm{Bu}$ gün çalışma hayatında en önemli konulardan biri haline gelmiş olan iş sağlığı ve güvenliği kavramı, pek çok alanda tanımlanmıştır. Dünya Sağlık Örgütü (WHO) ve Uluslararası Çalışma Örgütü (ILO) ilkelerine göre iş̧̧i sağlığı ve iş güvenliği, "Tüm çalışanların bedensel, ruhsal ve toplumsal sağlık ve refahlarının en üst düzeye yükseltilmesi ve bu durumun korunması; işyeri koşullarının, çevrenin ve üretilen malların getirdiği sağlığa aykırı sonuçların ortadan kaldırılması" olarak tanımlanmıştır [1-5]. Daha sonra yapılan tüm tanımlar; WHO ve ILO örgütlerinin yapmış olduğu bu tanım çerçevesinde genişletilmiştir. İs sağlığı ve güvenliği ekonomik boyutları bir yana sosyal boyutları itibariyle de ülke kalkınması açısından hayati öneme haiz toplumsal bir olgudur. Sağlıklı ve güvenli bir işyeri ortamı daha verimli çalışmanın ön koşuludur ve özellikle gelişmekte olan ülkelerde toplumsal kalkınmanın belirleyici unsurları arasında yer almaktadır [5]. Ülkemizde iş sağlığı ve güvenliği çalışmaları; 2003 yılında kabul edilen 4857 sayılı iş kanunun 5. bölümünde 77-89. maddeleri ve diğer kanunlardaki düzenlemeler ile yürütülmekteydi [6, 9]. 2012 y1linda kabul edilerek resmi gazetede yayınlanan 6331 sayı1lı İş sağlı̆̆ı ve güvenliği kanunu, başlı başına konuyu ele alan ilk ve tek kanundur. Yönetmelikler ve kanun maddeleri, tanımlamalar ve yaptırımlar açısından günümüze kadar değişiklikler göstermiştir. Sürekli değişen ve gelişen çalışma hayatında 2016 yllı itibari ile yaptırımları hayata geçecek olan iş sağlığı ve güvenliği kanununun etkileri önümüzdeki yıllarda daha ayrıntılı olarak ortaya konabilecektir.

İş kazası beklenmedik bir anda birden oluşan yaralanma, sakatlık ya da ölümle işçiyi etkileyen ve mal kaybı, hasar ya da üretimin durması ile ortaya çıkan bir durumdur [10-11]. Kaza kavramı genel olarak; kasit olmadan aniden meydana gelen ve arzu edilmeyen şekilde sonuçlanan olay olarak ifade edilir. Standartlarda ise kaza; ölüme, hastalığa, yaralanmaya, hasara veya diğer kayiplara sebebiyet veren istenmeyen olay olarak tanımlanmıştır [5]. Dünya sağlık örgütü; önceden planlanmamış, çoğu kez kişisel yaralanmalara, makinalar ile araç ve gereçlerin zarara uğramasına, üretimin bir süre durmasına yol açan bir olay olarak; Uluslararası çalışma teşkilatı ise önceden planlanmayan, beklenmeyen, belirli bir zarar ya da yaralanmaya neden olan bir olay olarak tanımlamışı ır [12]. Çok sayıda ve geniş tanımlamalar ile anlatılmaya çalışılsa da iş sağlığı, meydana gelen iş kazaları ile somut bir gerçek olarak karşımızda durmaktadır. Bu aşamada yapılması gereken bu gerçeği ayrıntılı olarak irdelemektedir. Geçtiğimiz y1l meydana gelen maden kazaları başta olmak üzere ülkemizde her geçen gün ölümlü iş kazası sayıları artmaktadır. Meydana gelen diğer iş kazalarında ise geçici veya kalıcı iş göremezlik sonucu hem çalışanlar, hem işverenler hem de ülke ekonomisi olumsuz etkilenmektedir.

$\mathrm{Bu}$ çalışmada resmi veriler kullanılarak son y1llarda meydana gelen tüm kazaların zaman dağılımlarından faydalanılmış, kaza-zaman yoğunlukları aylık ve günlük olarak belirlenmiştir. Aynı şekilde iş kazası geçiren çalışanların iş deneyimleri ile iş kazası arasındaki ilişki yorumlanmıştır. Sonuçlar, kazaların meydana gelme nedenleri açısından değerlendirilmiştir. Geçtiğimiz yıllarda meydana gelen iş kazaları temel mühendislik kollarındaki faaliyet alanları açısından incelenmiştir. Yine bu faaliyet alanlarındaki ölümlü iş kazaları, geçici iş göremezlik süreleri ortaya konmuştur.

\section{MATERYAL}

Hedeflenen amaçları gerçekleştirmek amacıyla Sosyal güvenlik kurumuna (SGK) ait istatistik yıllıkları kullanılmıştır [13-17]. 20102014 yıllarına ait tüm yıllıklar tek tek incelenmiş ve veriler gözden geçirilmiştir. İş kazası kayıtları, öncelikle zamanlama açısından aylık ve günlük olarak ayrı ayrı tasnif edilmiştir. Ayrıca SGK sinıflamasina giren 99 adet faaliyet sinıfi, mühendislik bilimleri açısından yeniden derlenmiştir. Derleme sonucu oluşturulan yeni gruplamalar Çizelge 1'de verilmiştir. 
Çizelge 1. Mühendislik çalışmalarına göre faaliyet grupları [13-17]

\begin{tabular}{|l|l|}
\hline Mühendislik Çalışmaları & SGK kayıtlarındaki Faaliyet Kolları \\
\hline Ziraat & Bitkisel ve hayvansal üretim ile avcılık ve ilgili hizmet faaliyetleri \\
\hline Maden & $\begin{array}{l}\text { Kömür ve linyit çıkartılması } \\
\text { Ham petrol ve doğalgaz çıkarımı } \\
\text { Metal cevheri madenciliği } \\
\text { Diğer madencilik ve taş ocakçılığı } \\
\text { Madenciliği destekleyici hizmet faaliyetleri }\end{array}$ \\
\hline Tekstil & $\begin{array}{l}\text { Tekstil ürünlerinin imalatı } \\
\text { Giyim eşyalarının imalatı }\end{array}$ \\
\hline Gıda & $\begin{array}{l}\text { Gida ürünlerinin imalatı } \\
\text { İçeceklerin imalatı }\end{array}$ \\
\hline Makine & Başka yerde sınıflandırılmamış makine ve ekipman imalatı \\
\hline Otomotiv-Uçak-Gemi & $\begin{array}{l}\text { Motorlu kara taşıtı, treyler (römork) ve yarı treyler (yarı römork) imalatı } \\
\text { Diğer ulaşım araçlarının imalatı }\end{array}$ \\
\hline İnşaat & $\begin{array}{l}\text { Bina inşaatı } \\
\text { Bina dışı yapıların inşaatı } \\
\text { Özel inşaat faaliyetleri }\end{array}$ \\
\hline
\end{tabular}

Toplamda 17 faaliyet alanı ayırt edilerek gruplandırmaya dahil edilmiştir. Temel mühendislik bilimleri açısından değerlendirilen faaliyet alanları sekiz adet alt grupta birleştirilmiştir. Gruplandırma sonucu faaliyet alanlarına göre SGK sinıflamasında 72 adet faaliyet alanı ayrı tutulmuştur.

Mühendislik çalışmaları ve bunlara dahil olan faaliyetler iki nedenden ötürü ayrı gruplanmıştır. Birinci neden son yıllarda meydana gelen iş kazalarının inşaat ve madencilikte yoğunlaşmış olmasıdır. İkinci neden ise, mühendislik çalışmalarının gözlenebilir ve ölçülebilir yapıda olmasıdır. Genel olarak bakıldığında sanayi çalışmaları başta olmak üzere tüm faaliyet alanlarının temelinde mühendislik çalışmaları bulunmaktadir.

Tüm faaliyet alanlarda gelişme göstermek isteniyorsa bu gelişmelerin temel alanlarda başlaması gerekmektedir. $\mathrm{Bu}$ nedenle faaliyet yerine mühendislik alanlarına yönelinmiş, mevcut faaliyetler en yakın mühendislik alanlarına dâhil edilmiştir. Belirlenen gruplar için kaza istatistikleri yeniden oluşturulmuştur. Yıllara göre, iş kazası geçiren sigortalı sayıları Çizelge 2'de verilmiştir [13-17]. İş kazası geçiren sigortalıların yatarak ve ayakta tedavileri birleştirilmiş ve yıllara göre geçici iş göremezlik süreleri gün bazında derlenmiştir (Çizelge 3). Ölümle sonuçlanan iş kazaları gruba dahil edilmemiş ileriki bölümlerde ayrı olarak sunulmuştur. 
Çizelge 2. İş kazası geçiren sigortalı sayısı (2010 - 2014) [13-17]

\begin{tabular}{lccccc}
\hline \multirow{2}{*}{ Mühendislik kolu } & \multicolumn{5}{c}{ İs kazası geçiren sigortalı sayıs1 } \\
\cline { 2 - 6 } Ziraat & 2010 & $\mathbf{2 0 1 1}$ & $\mathbf{2 0 1 2}$ & $\mathbf{2 0 1 3}$ & $\mathbf{2 0 1 4}$ \\
Madencilik & 380 & 380 & 504 & 1362 & 1678 \\
Tekstil & 9081 & 10558 & 9963 & 14304 & 13049 \\
Gıda & 4351 & 4024 & 5970 & 13303 & 14627 \\
Makine & 2504 & 2661 & 3035 & 9399 & 11304 \\
Otomotiv & 1981 & 2218 & 2235 & 5113 & 5415 \\
İnşaat & 6584 & 2235 & 1919 & 1856 & 7821 \\
Genel & 6437 & 7749 & 9209 & 26967 & 29699 \\
Tüm Faaliyet Kolları & 371 & 120 & 110 & 105 & 755 \\
\hline
\end{tabular}

Çizelge 3. İş kazasına bağlı geçici iş göremezlik süresi (2010-2014) [13-17]

\begin{tabular}{lccccc}
\hline \multirow{2}{*}{ Mühendislik kolu } & \multicolumn{5}{c}{ İş kazasına bağlı geçici iş göremezlik süresi (gün) } \\
\cline { 2 - 6 } Ziraat & $\mathbf{2 0 1 0}$ & $\mathbf{2 0 1 1}$ & $\mathbf{2 0 1 2}$ & $\mathbf{2 0 1 3}$ & $\mathbf{2 0 1 4}$ \\
Madencilik & 10662 & 12832 & 12034 & 15564 & 17017 \\
Tekstil & 173756 & 198778 & 173404 & 173322 & 133430 \\
Gıda & 78327 & 75303 & 94072 & 137264 & 135715 \\
Makine & 56187 & 58097 & 61859 & 95527 & 93312 \\
Otomotiv & 41922 & 51690 & 46266 & 63961 & 51430 \\
İnşaat & 63029 & 34673 & 36591 & 31078 & 62031 \\
Genel & 241134 & 319209 & 309441 & 457437 & 358536 \\
Tüm Faaliyet Kolları & 47443 & 3762 & 5024 & 3316 & 5737 \\
\hline
\end{tabular}

\section{ARAȘTIRMA BULGULARI}

\section{1. İş Kazalarına Genel Bakış}

SGK verileri kullanılarak, 2010-2014 y1lları arasında meydana gelen iş kazalarının yıllara göre dağılımları incelenerek Şekil 1 oluşturulmuştur.
2010 yılında 62716 olan iş kazası geçiren sigortalı sayıları, 2014 yılında 221366'ya yükselerek dramatik bir artış sergilemiştir. 2010-2012 y1lları arası ortalama iş kazası sayısı 68273 iken 2013 ve 2014 yıllarındaki ani yükseliş beş yıllık ortalamayı 123515 'e çıkartmıştır. 


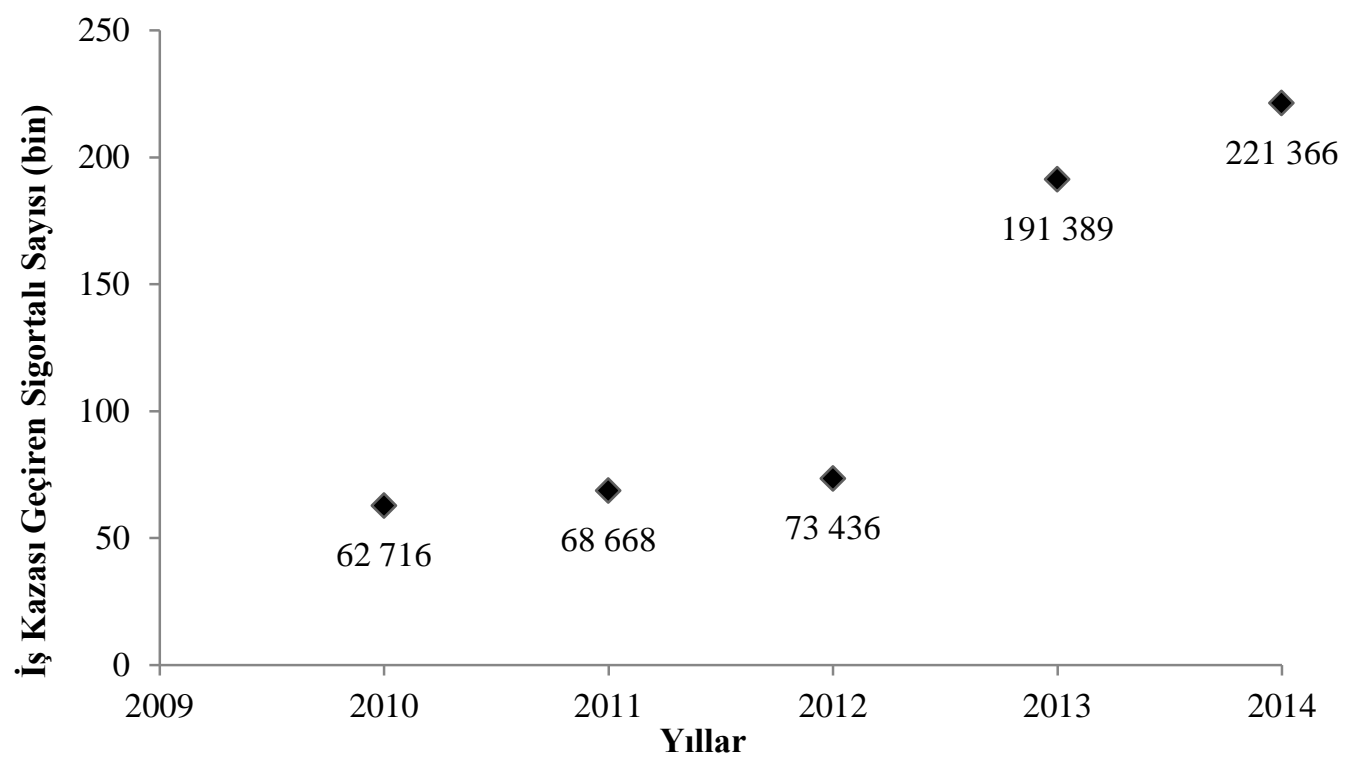

Şekil 1. İş kazası geçiren sigortalı sayılarının yıllara göre dağılımı

\subsection{Kaza-Zaman Yoğunluğu}

Son yıllarda meydana gelen iş kazalarının aylık dağılımları incelendiğinde, Mayıs- Ağustos aylarında belirgin bir yoğunlaşma olduğu gözlenmiştir (Şekil 2). Söz konusu bu aylarda 2013-2014 yıllarındaki ani yükseliş daha fazla göze çarpmaktadır. Çalışanlardaki dikkat eksikliğinin yaz aylarında artmasının yanı sıra, bazı mühendislik çalışmalarının (madencilik, inşaat) kış aylarında hava koşulları nedeniyle kısıtlanması bu tabloyla karşı karşıya kalınmasının sebepleri olarak sayllabilmektedir.

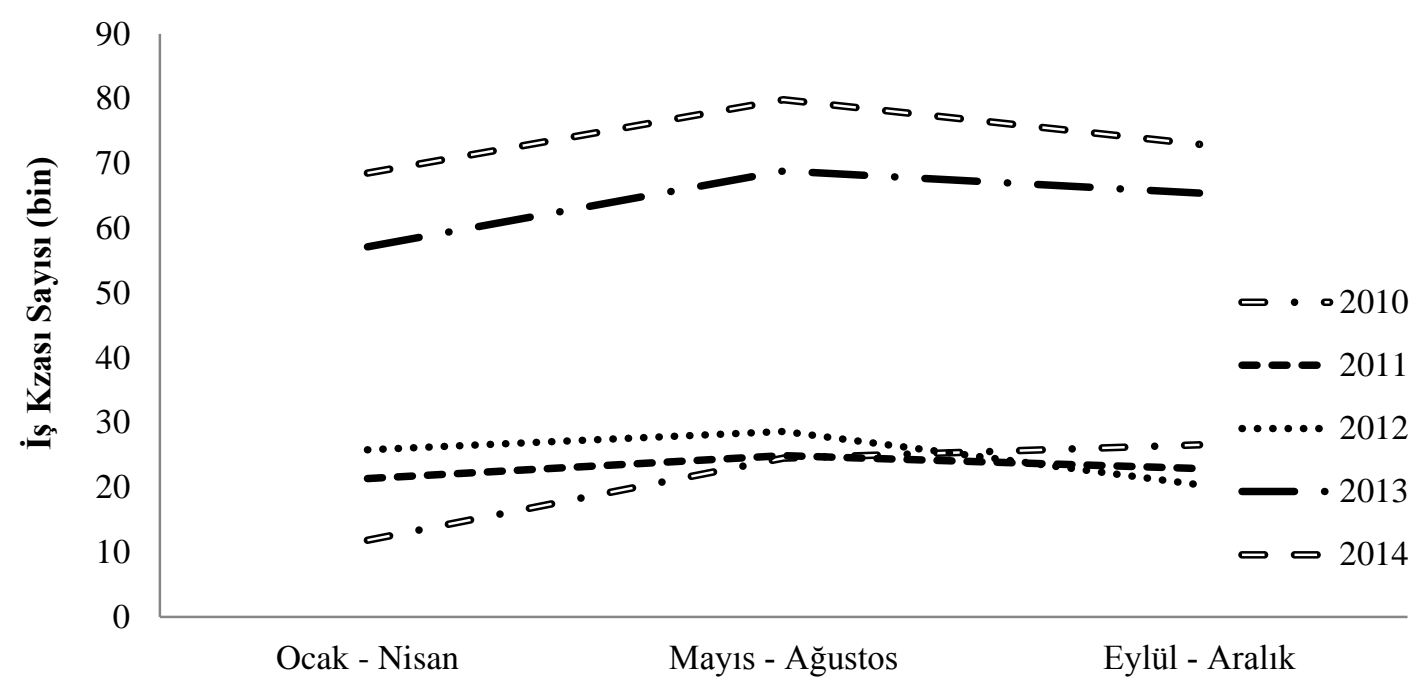

Şekil 2. Aylık iş kazası verileri grafiği 
Çalışanların aylık iş kazası istatistikleri incelendikten sonra, günlük istatistikler de incelenmiş ve kaza-zaman göstergesi grafiği oluşturulmuştur (Şekil 3). Yapılan incelemede özellikle günlük vardiyanın denk geldiği 08:00-18:00 saatleri arasında iş kazalarının yoğunlaştığı gözlenmiştir. Daha ayrıntılı incelendiğinde, beş yıllık tüm verilerde, sabah ve öğlen saatleri arasında ani yükselişler gözlenirken, öğleden sonraki ilk saatlerde de benzer bir yükseliş ayırt edilmektedir. Tespit edilen bu zaman dilimleri kaza-zaman yoğunluğu olarak adlandırılmıştır. $\mathrm{Bu}$ tanımdan yola çıkarak, yaz ayları ve gündüz

\section{3. İş Kazası ve Çalışan Deneyimi İlişsisi}

Çalışanların iş kazası geçirdikleri zaman itibari ile geçen çalışma süreleri incelenmiş ve kaza-deneyim ilişkisi ortaya konmuştur (Şekil 4). Beş yıllık kaza istatistiklerine göre, bir aylık çalışmalar ile 10 yıla kadar yapılan çalıșmalarda iş kazası oranları artmaktadır. Üç ay ve bir yıl arasında çalışma deneyimi olan çalışanların en çok iş kazası ile karşı karşıya olan grup olduğu gözlenmiştir.

Daha açık bir ifade ile her ne kadar belirli deneyim aralıklarında yoğunlaşma fark edilse de deneyimin iş kazasını azalttığı ile ilgili bir yorum yapmak uygun değildir. Nitekim deneyimsiz olarak adlandırılabilecek günlük çalışanlarda meydana gelen kaza sayıları en deneyimli grupla karşılaştırıldığgnda oldukça düşüktür.

Daha açık bir ifade ile 1 günlük ve 7 günlük çalışanların geçirdikleri iş kazası sayıları yılların hiç birinde on yıldan fazla deneyime sahip olan çalışanların geçirdikleri iș kazası sayısına erişmemiştir. $\mathrm{Bu}$ durum iş kazasının deneyimle ilişkilendirilmemesi gerektiğini ortaya koymaktadir.

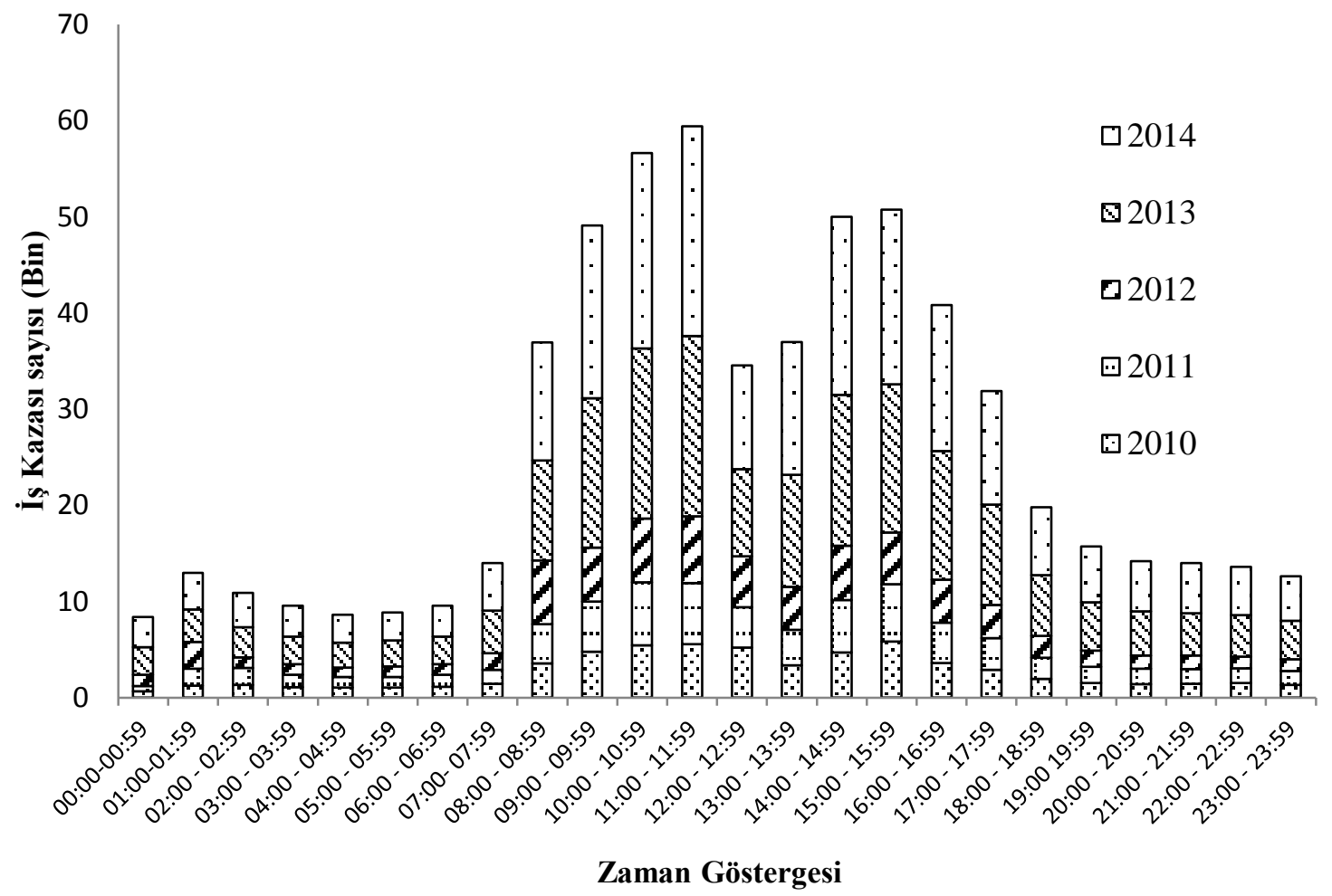

Şekil 3. Saatlik iş kazası verilerinin yıllara göre yığışım grafiği 


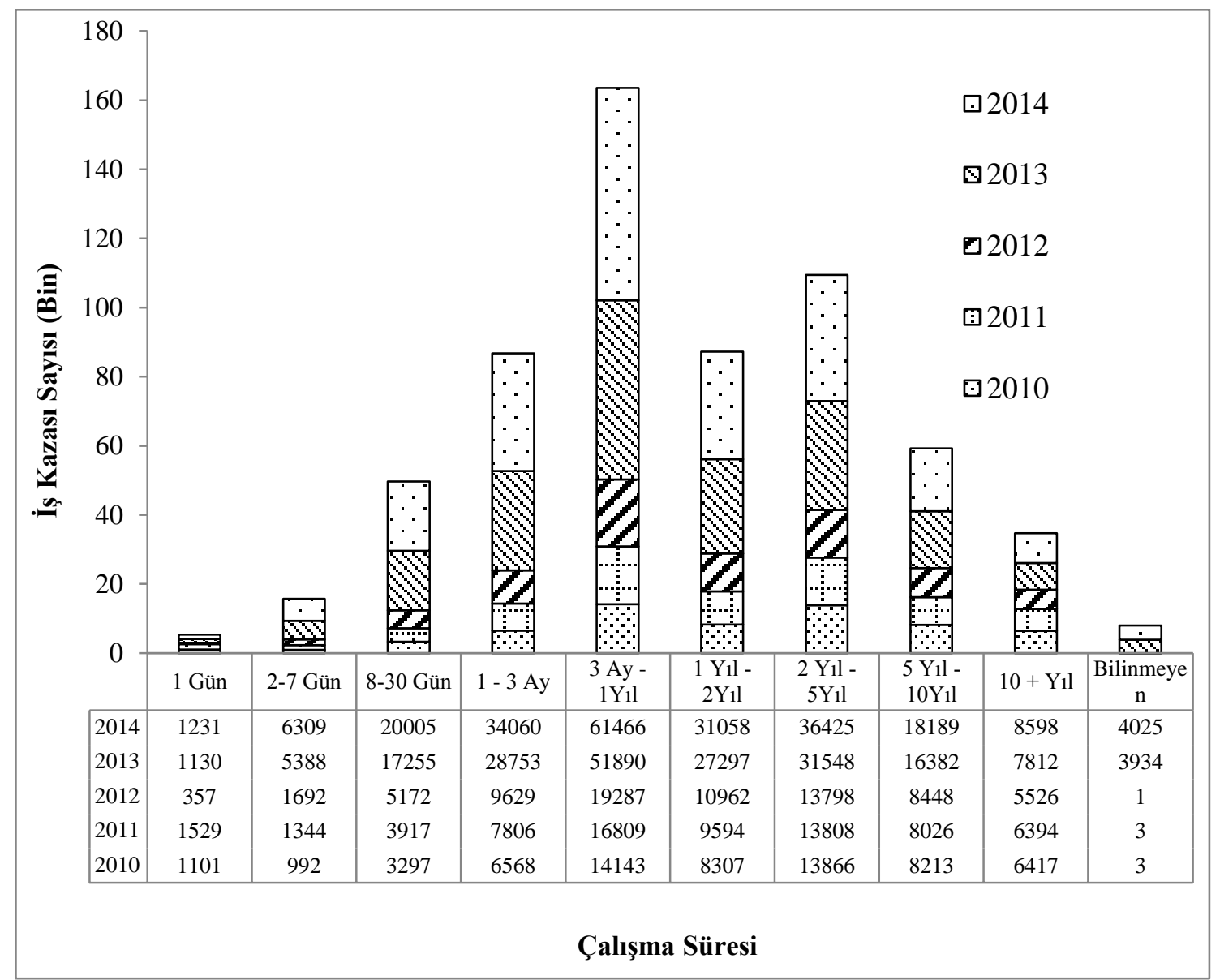

Şekil 4. İş kazası ve çalışan deneyimi ilişkisi grafiği

\subsection{Mühendislik Çalıșmalarında Kaza İstatistikleri}

Karşılaşılan bu tabloyu daha ayrıntılı analiz edebilmek için değişkenlerin gruplanması uygun görülmüştür. İş kazalarının yoğunlaştığı düşünülen ana mühendislik dalları ile ilgili çalışmalar Çizelge 1'deki sınıflamalar kullanılarak tasnif edilmiştir.

Yapılan gruplandırma ölçütünün uygunluğunu gözler ününe sermek amaciyla ölümlü iş kazalarının dağılımları incelenmiştir. Belirlenen gruplara karşılık, kalan faaliyet alanlarında gerçekleştirilen çalışmalarda her yıl gerçekleşen ölümlü iş kazalarının oranları hesaplanmıştır
(Şekil 5). Yapılan hesaplamalar ile 99 faaliyet alanından 8'inin oluşturduğu mühendislik grubu çalışmaların ölümlü iş kazalarının yarısından fazlasını oluşturduğunu ortaya konmuştur. Tüm yılların ortalaması alındığında mühendislik faaliyetlerinin, \%54,6 ile kayıpların en çok yaşandığı çalışma alanları olduğu belirlenmiştir. Ortaya atılan bu sonuç ile yapılan gruplandırmanın uygun olduğu tespit edilmiştir.

Çizelge 1'de daha önce tespit edilen mühendislik alanlarına ait son beş yıllık istatistikler incelenerek ayrıntılı bir çalışma gerçekleştirilmiştir. $\mathrm{Bu}$ çalışma çerçevesinde öncelikle mühendislik kollarına karşılık iş kazası geçiren sigortalı sayıları derlenmiştir (Şekil 6). 


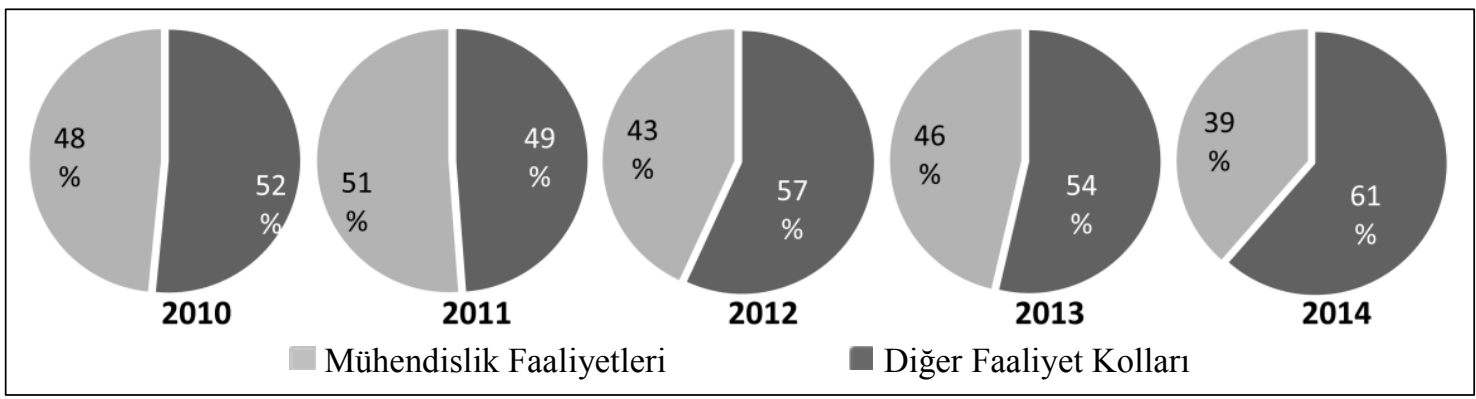

Şekil 5. İş kazası geçiren sigortalı sayılarının faaliyet kollarına göre oranları [13-17]

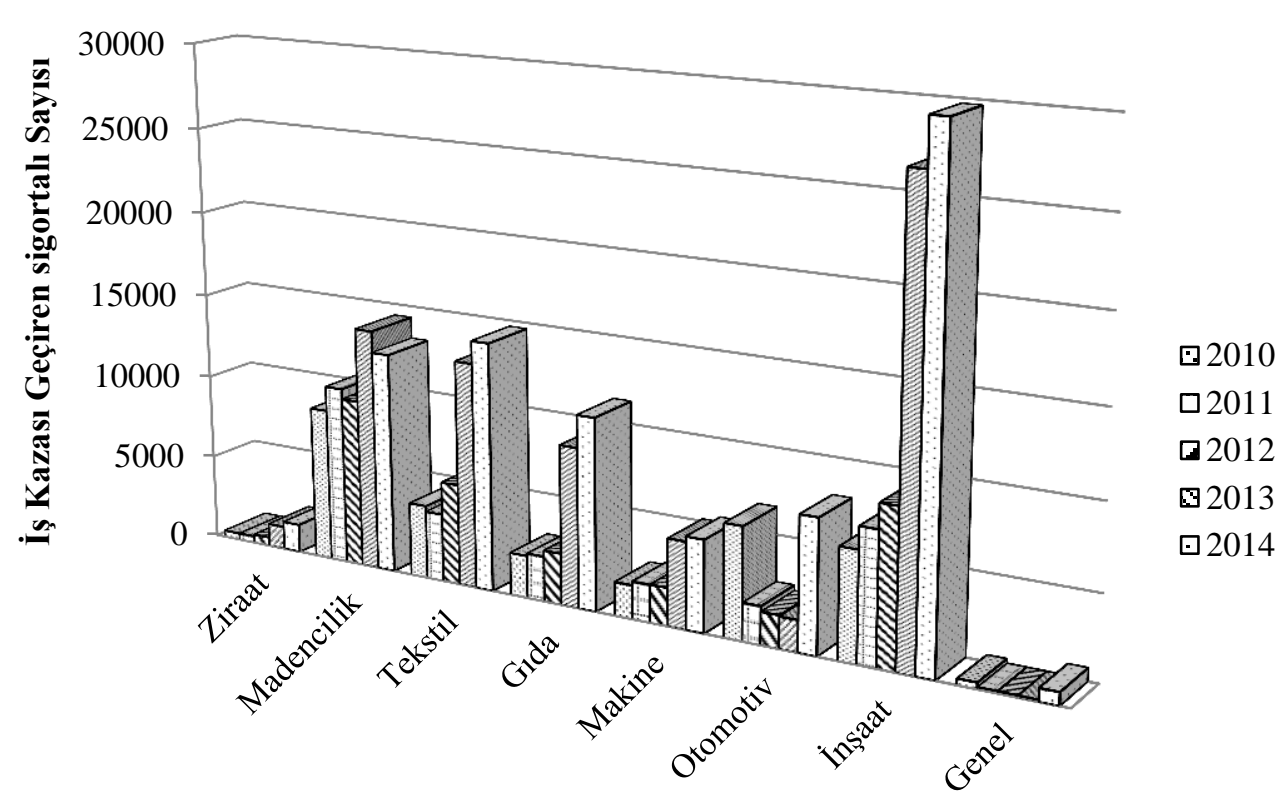

Mühendislik Kolu

Şekil 6. Mühendislik kollarına göre iş kazası geçiren sigortalı sayıları

Şekil 6'da verilen grafikte inşaat faaliyetlerinin, en çok kazanın yaşandığı mühendislik çalışmaları olduğu göze çarpmaktadır. İnşaat faaliyetlerini takiben madencilik, tekstil ve gida ile ilgili mühendislik çalışmalarında fark edilmektedir. 2014 yılı verileri incelendiğinde, 29699 ile inşaat, 14627 ile tekstil, 13049 ile maden mühendisliği ve bunlarla ilgili faaliyet alanları iş kazası sıralamasının ilk basamağını oluşturmaktadır.

Son beş yıla ait iş kazaları sonucunda meydana gelen iş gücü kayıpları incelendiğinde ilk üç mühendislik alanının değişmediği belirlenmiştir (Şekil 7). 2014 y1lı istatistikleri göz önüne alındığında 358536 gün le inşaat faaliyetleri birinci sırayı alırken 135715 gün ile tekstil ikinci, 133430 gün ile madencilik üçüncü iş günü kayıplarının meydana geldiği mühendislik ile ilgili çalışmalar olarak göze çarpmaktadır. İş kazasına bağlı ölümlerin son beş y1lın istatistikleri yeniden tasnif edilmiş ve her yıla ait kayıp sayılara karşılık mühendislik kollarının gösterildiği bir grafik hazırlanmıştır (Şekil 8). İnşaat ve madencilik çalışmaları ölümlü iş kazalarının en yoğun faaliyet 
kolları olarak ortaya çıkmaktadır. 2014 verilerine göre bu iki mühendislik kolu ve bunlara yardımcı faaliyetler sadece mühendislik gruplarında değil tüm faaliyet kolları arasından en yüksek ölümlü kaza oranına sahip faaliyet kollarını oluşturmaktadır. $\mathrm{Bu}$ açıdan bakıldığında tedbir alınması gereken en önemli faaliyet kolları oldukları söylenebilmektedir. Özellikle 2014 yılında meydana gelen iki büyük iş kazası madencilik faaliyetlerini diğer faaliyet kollarından daha hızlı bir yükselişte bulunmasına yol açmıştır.

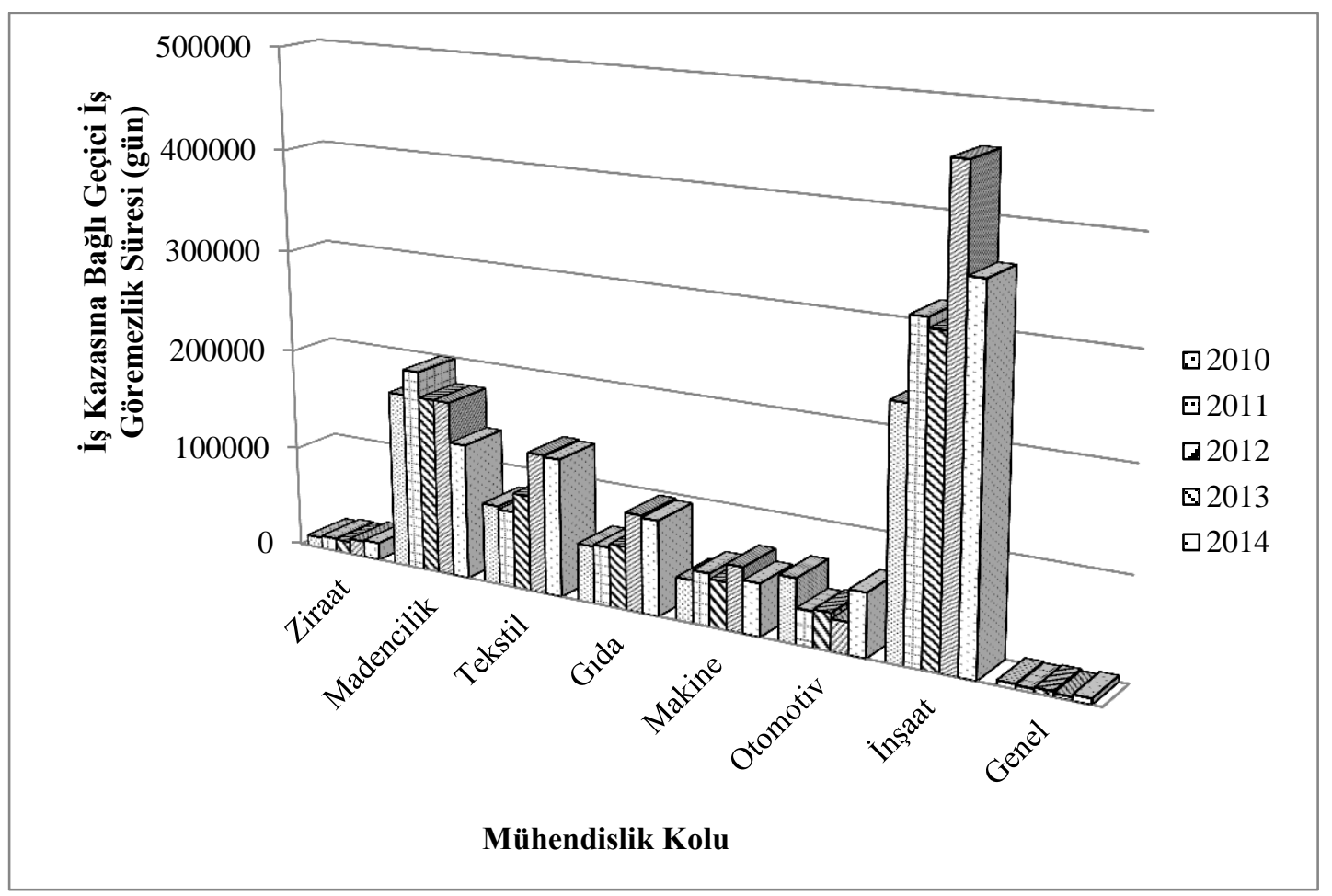

Şekil 7. Mühendislik kollarına göre iş kazasına bağlı geçici iş göremezlik süreleri (gün)

İş kazasına bağlı ölümlere ait son beş yılın istatistikleri yeniden tasnif edilmiş ve her yıla ait kayıp sayılarına karşılık, mühendislik kollarının gösterildiği bir grafik hazırlanmıştır (Şekil 8).

İnşaat ve madencilik çalışmaları ölümlü iş kazalarının en yoğun yaşandığı faaliyet kolları olarak ortaya çıkmaktadır. 2014 verilerine göre bu iki mühendislik kolu ve bunlara yardımc1 faaliyetler sadece mühendislik gruplarında değil tüm faaliyet kolları arasında en yüksek ölümlü kaza oranına sahip faaliyet kollarını oluşturmaktadır [16].

$\mathrm{Bu}$ açıdan bakıldığında, tedbir alınması gereken en öncelikli faaliyet kolları oldukları söylenebilmektedir. Özellikle 2014 yılında meydana gelen iki büyük iş kazası madencilik faaliyetlerinin diğer faaliyet kollarından daha hızlı bir yükselişte bulunmasına yol açmıştır. 


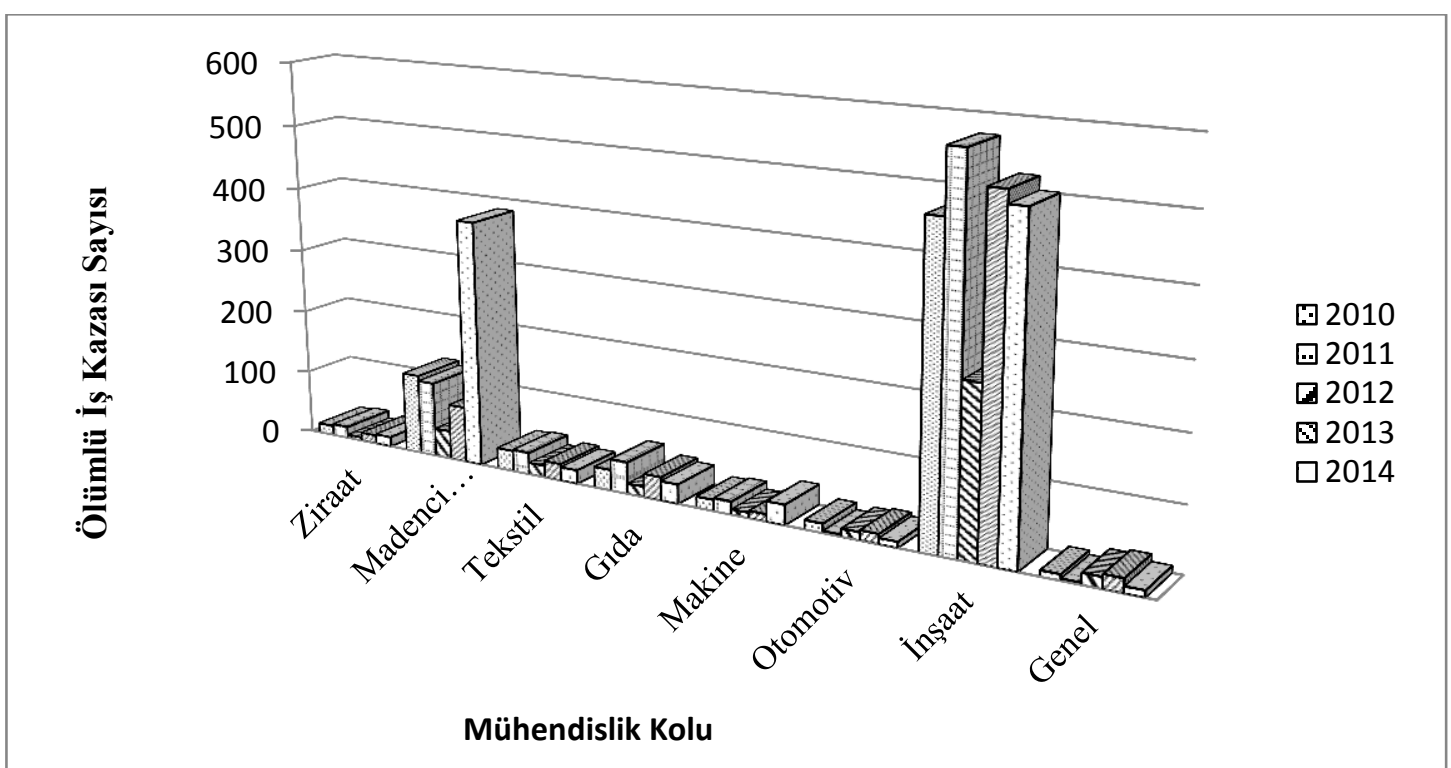

Şekil 8. Mühendislik kollarına göre ölümlü iş kazası sayıları

\section{REGRESYON ANALIZİ}

Çalışmada her mühendislik kolu için doğrusal regresyon modelleri oluşturulmuştur. Her bir faaliyet kolu için oluşturulan modellerin matematiksek fonksiyonları dağılım grafikleri üzerinde gösterilmiştir. Ayrıca iş kazasına bağlı ölümlerin yıllar ile arasındaki ilişki sorgulanmıştır.
Tahminler için bilinen x'ler (2010-2014 yılları), bilinen y’ler (ölümlü iş kazaları sayısı) arasındaki regresyon eğrisinin formülü kullanılarak hesaplama yapilabilmektedir [18-21]. Regresyon analizi için yıllık ölümlü kaza istatistiklerinden yararlanılarak tüm faaliyet alanları ve mühendislik kollarına ait dağılım grafikleri oluşturulmuştur (Şekil 9 ve 10).

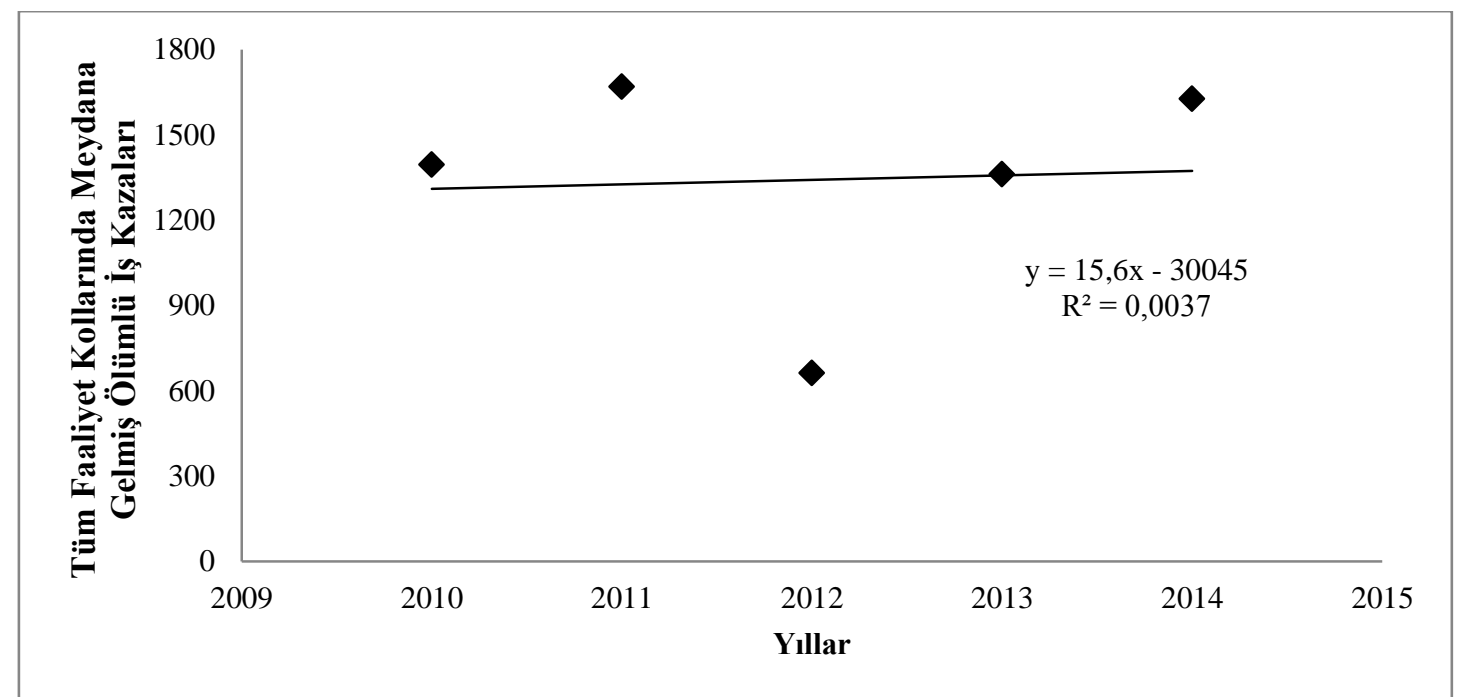

Şekil 9. Yıllar ile tüm faaliyetlerde meydana gelen ölümlü iş kazalarının regresyon eğrileri ve denklemleri 


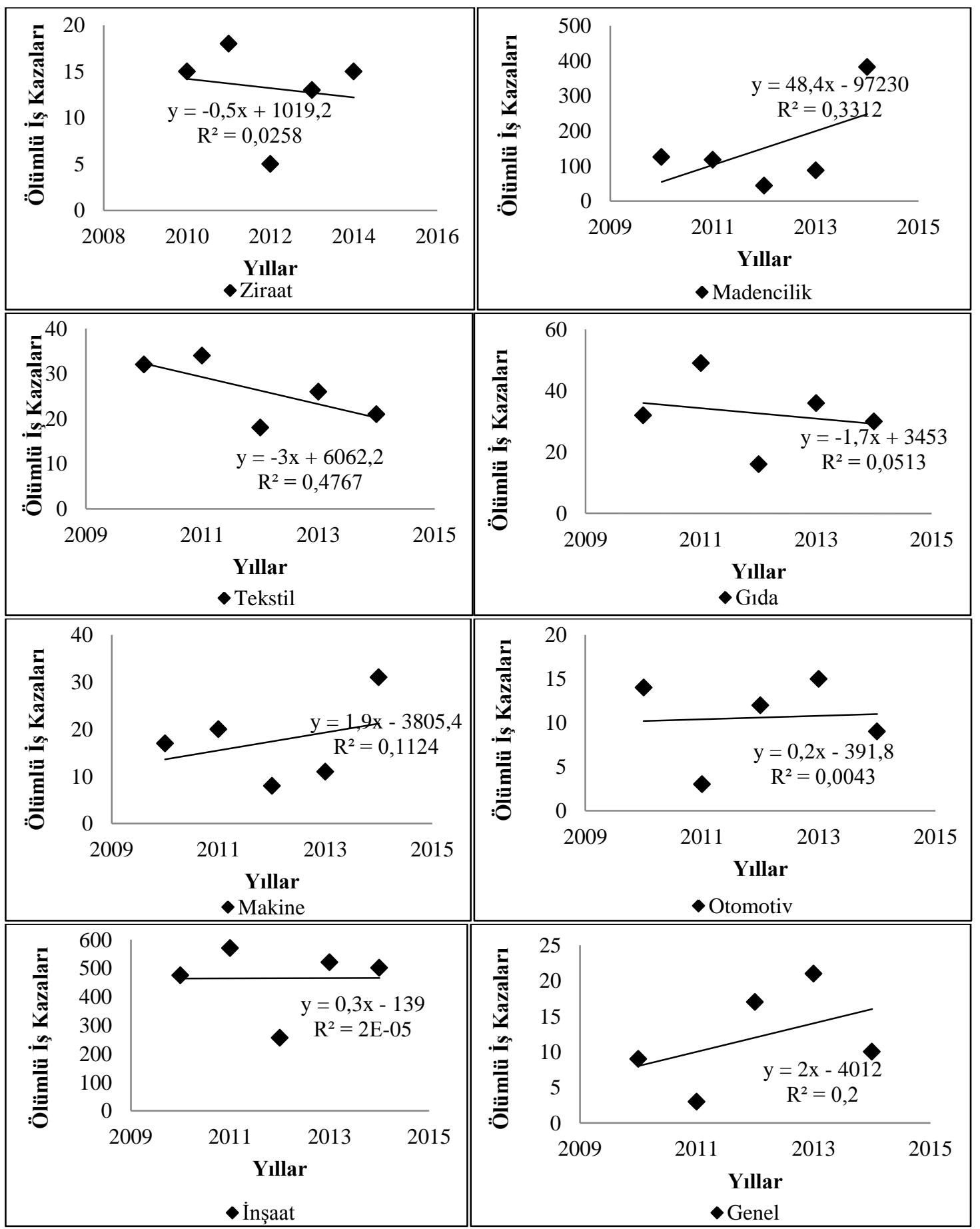

Şekil 10. Yıllar ile mühendislik kollarında meydana gelen ölümlü iş kazalarının regresyon eğrileri ve denklemleri 
Oluşturulan dağılım grafiklerindeki noktaları temsil eden regresyon eğrileri çizilmiş ve bu eğrilerin matematiksel fonksiyonları grafikler üzerinde verilmiştir. Faaliyet kollarına ait grafiklerin her birinde regresyon eğrisinin denklemi ve $\mathrm{R}^{2}$ değerleri verilmiştir (Şekil 9 ve 10). $\mathrm{R}^{2}$ regresyon denkleminin açıkladığ 1 "değişkenlik oranıdır. Buna göre, oranın alacağı değer, regresyon denkleminin başarı ölçüsü olarak kullanabilmektedir. $\mathrm{Bu}$ orana "denklemin belirleme katsay1s1 (R2)" denilmektedir [22]. R değerleri incelendiğinde bağımsız değişkenin bağımlı değişkeni açıklama oranının düşük olduğu gözlenmiştir. Başka bir değişle regresyon denkleminin tahmin gücü düşüktür.
Ölümlü iş kazası sayılarındaki değişimin yıllardaki değişimle açıklanması uygun değildir. Açıklama oranının yükselmesi için yıllara ait veri sayısının daha fazla olması veya korelasyon katsayının yüksek olması gerekmektedir. Korelasyon katsayısı, bağımlı ve bağımsız değişkenler arasındaki "doğrusal" bağıntının düzeyini ölçmeyi öngörür. Değişkenler arasındaki ilişkinin derecesini ve yönünü belirten; ölümlü iş kazaları ve yıllara ait korelasyon katsayıları,her faaliyet kolu için ayrı ayrı hesaplanmış ve hesaplama sonuçları, diğer istatistikler ile birleştirilerek Çizelge 4'de verilmiştir.

Çizelge 4. Ölümlü iş kazalarının 2010-2014 verileri ve korelasyon katsayıları

\begin{tabular}{l|ccccccc} 
Faaliyet Kolu & 2010 & 2011 & 2012 & 2013 & 2014 & Ortalama & $\begin{array}{c}\text { Korelasyon } \\
\text { Kataysı }\end{array}$ \\
\hline Ziraat & 15 & 18 & 5 & 13 & 15 & 13 & $-0,161$ \\
\cline { 2 - 7 } $\begin{array}{l}\text { Madencilik } \\
\text { Tekstil }\end{array}$ & 125 & 117 & 44 & 87 & 382 & 151 & 0,575 \\
\cline { 2 - 7 } & 32 & 34 & 18 & 26 & 21 & 26 & $-0,690$ \\
Gıda & 32 & 49 & 16 & 36 & 30 & 33 & $-0,227$ \\
\cline { 2 - 7 } Makine & 17 & 20 & 8 & 11 & 31 & 17 & 0,335 \\
\cline { 2 - 7 } $\begin{array}{l}\text { Otomotiv } \\
\text { İnşaat }\end{array}$ & 14 & 3 & 12 & 15 & 9 & 11 & 0,066 \\
\cline { 2 - 7 } Genel & 475 & 570 & 256 & 521 & 501 & 465 & 0,004 \\
\cline { 2 - 7 } & 9 & 3 & 17 & 21 & 10 & 12 & 0,447 \\
\cline { 2 - 7 } & 1394 & 1668 & 661 & 1360 & 1626 & 1342 & 0,061 \\
\hline
\end{tabular}

Ziraat ve gıda faaliyet kollarındaki ölümlü iş kazası sayıları ile yıllar arasında zayıf negatif bir ilişki içinde olduğu, bunların yanı sıra tekstil mühendisliği ve yardımcı faaliyet kollarındaki ölümlü kaza sayısı ve yıllar arasında negatif yönlü düşük bir ilişki görülmüştür. Buna karşın Makine, otomotiv ve inşaat faaliyetlerinde bir ilişkiden söz etmek oldukça güçtür. Madencilik faaliyetlerinde ise son yıllarda meydana gelen kaza sayılarındaki artış nedeniyle değişkenler arasında pozitif yönlü düşük bir ilişki bulunmaktadır (Çizelge 4).
Genelde doğrusal bir tahminin güvenilir sonuçlar verebilmesi için; değişkenler arasındaki ilişkinin kuvvetli, verilerin ortalamadan sapmaları düşük ve veri sayısının yeterli (teorikte 20 ve üzeri) olmas1 beklenmektedir. Benzer şekilde verilerde ortalamadan sapma gösteren değişken grupları vardır. Örneğin; madencilik çalışmalarında, 2014 yılında meydana gelen ölümlü kazalarda ani bir yükseliş yaşanmış, buna paralel olarak yıllar ortalaması da yükselmiştir. $\mathrm{Bu}$ durum regresyon eğrisinin eğimini arttırmasına neden olduğu gibi 
yapılacak tahminleri olumsuz etkileyeceği düşünülmektedir. Makine mühendisliği ve yardımcı faaliyet kollarında 2014 yılında gözlenen yükselme yukarı tahmini aynı şekilde etkilemektedir (Şekil 10). İlerleyen yıllarda gözlem sayısının artmasıyla ani yükselmelerin tahmine etkisi azalacak, gerekirse aykırı değer analizleriyle etkisi minimize edilebilecektir. Değişkenler arasındaki ilişkinin düzeyi ve regresyon denklemlerinin tahmin gücünün düşük olması nedeniyle sonraki yıllara ait ölümlü iş kazası sayılarının tahminlerinin güvenilirliği söz konusu değildir. $\mathrm{Bu}$ nedenle istatistik y1llkklarına ait tahminlerin daha sonraki yıllarda değerlendirilmesi gerekmektedir.

\section{SONUÇLAR VE ÖNERILER}

Çalışmada aşağıdaki sonuçlar elde edilmiştir.

1. Son beş yıla ait istatistikler incelendiğinde 2013 yılı itibari ile meydana gelen iş kazası sayısının sıçrama yaptığı ve 2014 yılında da bu tırmanışın devam ettiği belirlenmiştir.

2. Yaz ayları ve gündüz vardiyasına tekabül eden zaman periyodunun kaza-zaman yoğunluk alanı olduğu tespit edilmiştir.

3. Araştırma en çok iş kazası geçiren çalışanların, üç ay ile bir yıl arasında deneyim sahipleri olduğunu ortaya koymuştur. Bununla birlikte deneyimsiz çalışanların, en deneyimli (on yıldan fazla) çalışanlara göre daha az iş kazasıyla karşı karşıya kaldıkları anlaşılmıştır.

4. Mühendislik faaliyetleri açısından bakıldığında, çalışmada oluşturulan grupların uygunluğu ölümlü iş kazalarının oranları ile test edilmiştir. Tüm kazaların yaklaşık olarak yarısını mühendislik çalışmalarına dâhil edilen grupların oluşturduğu görülmüştür. $\mathrm{Bu}$ bakımdan gruplamanın uygun olduğu belirlenmiştir.

5. Gerek iş kazası sayıları gerekse kazalara bağlı iş günü kayıplarının incelenmesinde inşaat, tekstil ve madencilik çalışmalarının ilk üç sırada yer aldığ1 görülmüştür.

6. İş kazalarına bağlı ölümlerin ise en çok inşaat ve madencilik çalışmalarında meydana geldiği ayırt edilmiştir.
7. Sonraki yıllara ait tahminlerin yapılması; regresyon analizinin güvenilirliğinin düşük olması nedeniyle uygun olmadığı görülmüştür.

Tüm faaliyet alanlarında 2013 yılında gözlenen trendler nedeniyle iyimser tahminler yapılamamaktadır. 2012 yılındaki düşük kaza sayısı, 2013 yılı verilerin sıçramasına yol açmış olabileceği düşünülmektedir. Aynı yıllara ait SGK dökümleri incelendiğinde, meslek hastalıklarına ait çizelgelerde artık verilerin 2013 yılı verilerine eklendiği gözlenmiştir [15]. Benzer bir durumun iş kazaları istatistiklerinde açıklanmadığ görüldüğünden, kaynak veri tabanı doğru kabul edilmiştir. $\mathrm{Bu}$ nedenle son iki yılda yaşanan istatistiksel kırılmaların veri tabanından kaynaklanmadığı ifade edilebilir. Söz konusu kırılmaların nedenleri iş sağlığı ve güvenliği uygulamaları açısından ayrıntılı olarak araştırılmalıdır.

Tüm faaliyet kolları açısından kaza -zaman yoğunluk periyodlarında ek tedbirler alınması önerilmektedir. Deneyim süresi ayırt edilmeksizin tüm çalışanlar için iş sağlığı ve güvenliği bilinci geliştirilmeli, çalışana bağlı nedenlerle ortaya çıkan iş kazalarının önüne geçilmelidir.

İş kazaları verilerinin çeşitli istatistiklerle ortaya koyulduğu bu çalışmada, acil önlem alınması gereken iki ana mühendislik koluna dikkat çekilmiştir. En dikkat çekilmesi gereken sonuçlar; inşaat çalışmalarındaki iş kazalarının istikrarlı yükselişi ve 2014 yılında meydana gelen madencilik faaliyetlerindeki iş kazalarının ortaya çıkardığı ani yükseliştir. Bu iki durum önemle üzerinde durulması gereken sonuçlardır.

Yeterli sayıda örneklem olmaması ve çeşitli sektörlerde ani yükselmeler meydana gelmesi güvenilir bir tahmin yapılmasını engellese de, yapılan çalışma ile üzerinde dikkatle durulması gereken bir öngörü ortaya koyulmuştur. İlerleyen yıllarda elde edilen veri sayısının artmasıyla daha güvenilir tahminler yapılabilmesi mümkün olacaktır. Başka bir deyişle veri sayısı arttıkça; ortalamadan sapmaların tahmine etkisi azalacak, belki de doğrusal modeller yerine kullanılacak alternatif regresyon modelleri ile değişkenler 
arasındaki ilişki daha net bir șekilde ortaya koyulabilecek ve yapilacak tahminlerdeki hatalar azaltılabilecektir.

Çalışmada gerçekleştirilen basit doğrusal regresyon modeline bağlı regresyon analizleri, daha fazla bağımlı değişken kullanılarak geliştirilebilir. $\mathrm{Bu}$ amaçla öncelikle tahminlerin daha küçük gruplar için ayrı ayrı yapılması önerilmektedir. Her küçük grup için bağımlı değişkenler belirlenerek tahmin fonksiyonuna doğru şekilde etki etmesi sağlanmalıdır. Bu şekilde gerçekleştirilecek kestirimlerin güvenilirliğgi daha yüksek olacaktır.

Çalışmada resmedilen olumsuz tablonun önüne geçilebilmesi, iş sağlığı ve güvenliği tedbirlerinin alınabilmesine ve uygulanabilmesine bağlıdır. 2016 y1l itibari ile zorunlu hale gelecek uygulamaların ve bu uygulamaların 2015 yılındaki hazırlıklarının, ortaya konan bu negatif senaryoyu değiştireceği umulmaktadır.

\section{KAYNAKLAR}

1. Yardım, N., Çipil, Z., Vardar, C., Mollahaliloğlu, S., 2007. Türkiye İş Kazaları ve Meslek Hastalıkları: 2000-2005 Yılları Ölüm Hızları. Dicle Tıp Dergisi, 34(4), 264271.

2. Karacan, E., Erdoğan, Ö. N., 2011. İşçi Sağlığ Ve İş Güvenliğine İnsan Kaynakları Yönetimi Fonksiyonları Açısından Çözümsel Bir Yaklaşım. Kocaeli Üniversitesi Sosyal Bilimler Enstitüsü Dergisi (21) 2011 / 1 :102-116

3. Özçer, S., 1988. İşçi Sağlığ1 ve İş Güvenliğinin Çağdaş Anlamı. Verimlilik Dergisi-MPM Yayınları, Y11: 1988/2, Ankara.

4. Alli, B. O., 2001. Fundamental Principles of Occupational Health and Safety. OIT.

5. İşler M., C., 2013. T.C. Çalişma Ve Sosyal Güvenlik Bakanliği İş Teftiş Kurulu Başkanlığı İş Sağliği ve Güvenliği Eğitimleri İle Güvenlik Kültürünün İş Kazasi ve Meslek Hastaliklarinin Önlenmesindeki Etkisi İş Müfettişi Yardımcılığ Etüdü, Ankara.

6. Korkmaz, A., Avsallı, H., 2012. Çalışma Hayatında Yeni Bir Dönem: 6331 Sayılı İş Sağlığı ve Güvenliği Yasası, SDÜ Fen
Edebiyat Fakültesi Sosyal Bilimler Dergisi, Say1:26, ss.153-167.

7. 6331 Sayılı İş Sağlığı Ve Güvenliği Kanunu, http://www.resmigazete.gov.tr/eskiler/2012/06 120120630-1.htm, Erişim Tarihi: 22.10.2015

8. 4857 Sayılı İş Kanunu, http://www.mevzuat.gov.tr/MevzuatMetin/1.5 .4857.pdf, Erişim Tarihi: 22.10.2015

9. Dirican R., Bilgel N., 1993. Halk Sağlı̆̆1 (Toplum Hekimliği), Uludağ Üniversitesi Tıp Fak. Yayın1, 1993:429-52.

10. İlhan, M., N., Kurtcebe, Z. Ö., Durukan E., Koşar L., 2006. Temizlik İşçilerinin Sosyodemografik Özellikleri ve Çalışma Koşulları ile İş Kazası ve Meslek Hastalığı Sıklığı, Fırat Üniversitesi Sağlık Bilimleri Tıp Dergisi, Cilt 20, Say1 6, ss. 433-439.

11. Çalışma ve Sosyal Güvenlik Bakanlığı. İş Kazaları ve Meslek Hastalıkları, Hukuki ve Cezai Sorumluluklar http://www.csgb.gov.tr/csgbPortal/ShowPrope rty/WLP\%20Repository/itkb/dosyalar/ipm/isg 04 Erişim Tarihi: 22.10.2015

12. SGK İstatistik Y1llığ1, 2010, www.sgk.gov.tr, Erişim Tarihi: 19.05.2015

13. SGK İstatistik Yıllığ1, 2011, www.sgk.gov.tr, Erişim Tarihi: 19.05.2015

14. SGK İstatistik Y1llığ1, 2012, www.sgk.gov.tr, Erişim Tarihi: 19.05.2015

15. SGK İstatistik Yıllığı, 2013, www.sgk.gov.tr, Erişim Tarihi: 19.05.2015

16. SGK İstatistik Y1llığ1, 2014, www.sgk.gov.tr, Erişim Tarihi: 02.11.2015

17. Erdem, D., Kaan, M., Tanhan, F. http://istatistik.gen.tr/regresyon-analizi/ Erişim Tarihi: 03.11.2015

18. Ankara Üniversitesi Ders Notları, Regresyon Analizinin Temel Kavramları. http://acikders.ankara.edu.tr/pluginfile.php/15 24/mod_resource/content/2/2\%20Regresyon.pdf Erişim Tarihi: 03.11.2015

19. Ankara Üniversitesi Ders Notları, Korelasyon ve Tekli Regresyon Analizi-En Küçük Kareler Yöntemi. http://acikders.ankara.edu.tr/pluginfile.php/23 2/mod_resource/content/3/10-KorelasyonTekli\%20Regresyon-OLS.pdf Erişim Tarihi: 13.10.2015 
20. Akın,

M.

http://www.academia.edu/5382439/Regresyon analizi Erişim Tarihi: 02.11.2015

21. Harvard Üniversitesi, The $\mathrm{a}+\mathrm{bX}$ rule. http://isites.harvard.edu/fs/docs/icb.topic 97772 7.files/abx.pdf Erişim Tarihi: 28.10.2015

22. Günel, A., 2003. Regresyon Denkleminin Başarısını Ölçmede Kullanılan Belirleme Katsayısı ve Kritiği, Doğuş Üniversitesi Dergisi, 4 (2), 133-140. 
